\title{
Management of investment process in alternative energy projects
}

\author{
Olga Rostova ${ }^{1}$, Svetlana Shirokova ${ }^{1 *}$, Natalya Sokolitsyna ${ }^{1}$ and Anastasiia Shmeleva ${ }^{1}$ \\ ${ }^{1}$ Peter the Great St.Petersburg Polytechnic University, Polytechnicheskaya, 29, St. Petersburg, \\ 195251, Russia
}

\begin{abstract}
The article is devoted to the problem of creating favorable conditions and incentives for attracting investments in alternative energy projects in the regions. An analysis of Russian practice in the field of "green" financing showed that individual projects are being effectively implemented, but there is no established mechanism for attracting investments for "green" energy projects in the regions. The implementation of high-tech projects requires large amounts of investment, but in most cases, "green" business models are of high-risk and require a set of additional measures and incentives. The study suggests approach to the management of investment processes in regional alternative energy projects in accordance with the concept of green economy, formulates management algorithm, and gives full description of each stage. This work recommendations and results can be used in needed regions investment attractiveness raise measures elaboration for alternative energy projects realization.
\end{abstract}

\section{Introduction}

The renewable energy concept in recent years has received increasing public attention. Despite the fact that the environmental research economic aspects in the field of energy are widely covered in the domestic literature, but the problems associated with investments in alternative energy projects are not sufficiently developed. The concept of "alternative energy" appeared several decades ago, and is now one of the most popular areas for the activity of innovative companies all over the world. However, in Russia due attention to these issues began to be paid quite recently.

The "green" economy includes those activities that, in addition to modernizing and improving production efficiency, contribute to improving the quality of life and the living environment. "Green" economy focuses on meeting human needs, taking into account the interaction with the environment $[2,3]$.

Authors have researched situation in Russian renewable energy. One of the most developed areas is hydropower. About $17 \%$ of the generated energy in the overall balance of the country is hydroelectric power. The situation is worse with the development of other areas. The power industry based on other renewable energy sources in Russia currently provides less than $1 \%$ of the total electricity generation.

\footnotetext{
* Corresponding author: swchirokov@mail.ru
} 
The renewable energy projects development in Russia occurs with varying degrees of intensity [4]. The most actively implemented projects are based on the photoelectric conversion of solar energy. Mostly similar projects are implemented in the southern regions of Russia. This is due to suitable climatic conditions. Also promising are projects based on wind energy and small hydropower projects. Isolated and remote regions of Russia have the highest potential for the development of alternative energy.

The most suitable places for locating wind power stations are the coastal line of the Far North, as well as the Far East [5]. Geothermal method of obtaining alternative energy allows you to use the heat of the earth's crust. Russia produces about $10 \%$ of the world's geothermal energy. According to experts, only Kamchatka is capable of producing about 5 thousand MW of energy using geothermal sources.

One of the main problems of solar energy is the low efficiency of photovoltaic cells used. Among other drawbacks, it is also worth noting the variable volume of energy production, as well as the need for a large amount of free territory for the installation of photovoltaic cells. In the Russian Federation, the best places for building solar stations are the Krasnodar Territory, the Kuban, Primorye and Eastern Siberia.

Energy sources of plant origin can also be successfully used for energy. The most suitable regions for biomass processing are the Chernozem region, the Krasnodar Territory, the central part of Russia, and the South of Siberia.

However, there are a number of reasons why these promising areas have not been adequately developed. First, Russia is rich in fuel and energy raw materials. Currently, using traditional methods of obtaining energy is more commercially effective. To implement alternative energy projects, large amounts of investment are required, but in most cases "green" business models and projects are high-risk [6]. The main barriers to increasing investment in alternative energy projects include [7,8]:

- existing subsidies for the extraction of fossil fuels;

- insufficient institutional support;

- high initial costs and a long payback period of "green" investments;

- risks associated with the payback of the project;

- high information costs;

- technological risks;

- high costs associated with the integration of clean energy sources into the existing system.

Secondly, an obstacle to the implementation of such projects is the lack of the necessary infrastructure for the development of alternative energy, as well as the lack of qualified personnel able to work in this direction [9].

In order to increase investor interest in renewable energy projects and the transition to a green economy as a whole, new economic rules and mechanisms should be developed that would develop incentives for environmental behaviour and integrate them into everyday economic life. At the same time, the state should act not as a strict regulator, but as a partner and coordinator, and state funding should serve as a catalyst for private investment [10]. According to a research of factors stimulating green economy in China, stimulating central government measures are combined with local government measures. Such, for example, big enterprises are subsidized for energy-saving in national level, when a little enterprises are stimulated by municipal power $[11,12]$.

State sustainable development strategy must use complex territories development. According to the research, several regions have several possibilities in renewable energy sources projects development. The work aim is investment process management mechanism elaboration in regions for investments invitation to alternative energy projects. 


\section{Materials and methods}

An analysis of Russian practice has shown that individual alternative energy projects are being effectively implemented, but in the regions there is no established mechanism for attracting investments for such projects. The study suggests approach to investment process management in regional alternative energy projects according to green economy concept.

The authors considered this approach from the point of view of the purpose, object, method and subject of management. Management object is investment process, destined on developing prioritized green economy industries, allowing raising people life quality level taking into account harmonic environment relationship. Management subject - moving force, switching this mechanism, is regional power. Activity aim is creating conditions and opportunities system, interesting external and internal investors to invest needed resources in regional green economy investments object.

Thus, investment process management in region according to green economy concept is aimed regional power impact on investment activity conditions system for its maximal fit to investors' requests and stimulating their investment activity in green economy objects and destinations, one of which is alternative energy.

The methods used by the authors include tools and technologies to achieve the goal of creating a favorable investment climate that best meets the needs of investors and stimulates their investment activity in the "green" economy [13]. Particularly forming regional investment policy aims uses system analysis methods [14]. Finding specific regions investment attractiveness factors for alternative energy projects realization uses statistical analysis methods [15]. For a more reasonable allocation of budgetary resources of municipalities, an economic and mathematical model was developed, which allows to predict the level of development of controlled activities depending on the established priorities and a given amount of money [16].

Elaborated management system is based on the following principles:

- systematic principle means that investment climate must be considered from system approach point of view, consisting in considering interconnected subsystems (elements) in several hierarchy (decomposition) levels;

- competencies selection principle - consists in federal, regional and local management functions differentiation. This principle essence consists in giving preciously defined functions to each management subject and their legal fixation to it. And for each function realization law sets corresponding resources volumes and sources;

- coordination principle - investment process management system must ensure and monitor several federal, regional and private levels aims interconnection and noncontradiction;

- adaptively principle - ensuring management system flexibility and adaptively according to external and internal environment changes;

- aggregation principle - means that total all investment process system elements improvement helps to maximize synergetic effect (system elements relationship effect) This effect is sufficiently higher than autonomous not interconnected singular system elements impact effect;

- effectiveness principle assumes that investment process governance system ensures effective set aims achievement taking into account need to ensure not only economic, but social and ecologic effectiveness;

- alternatively principle assumes that regional investment policy elaboration must work alternative investment process development variants in region, which is concerned with this policy realization uncertainty conditions [17]. 


\section{Results}

In the study, the authors obtained the following results. The mechanism of management of investment process is presented by authors in the form of the scheme (Fig.1). It includes the following structural components:

1. Environment relationship block ensures link with environment and includes green economy strategic aims in national level coordination with region interests, researching competitors for investment resources, potential investors activity motives and economic expectations, and also stock markets condition. Since the interests of investors and the invested system do not always coincide, it is very important to establish the driving motives and expectations of all subjects of investment activity for their subsequent coordination.

2. Resource providing includes internal and external financing, and also resources, needed for investment process development (labor, material, intellectual, innovation etc.) [18].

3. Legal and methodic providing and regulation, regulating investment activity, are based on federal law and corresponding regional and local normative acts.

4. Organizational providing investment activity includes functioning needed organizational structures, ensuring acts on investment process management: initiation, investment situation analysis, planning, and regulation, set aims achievement control.

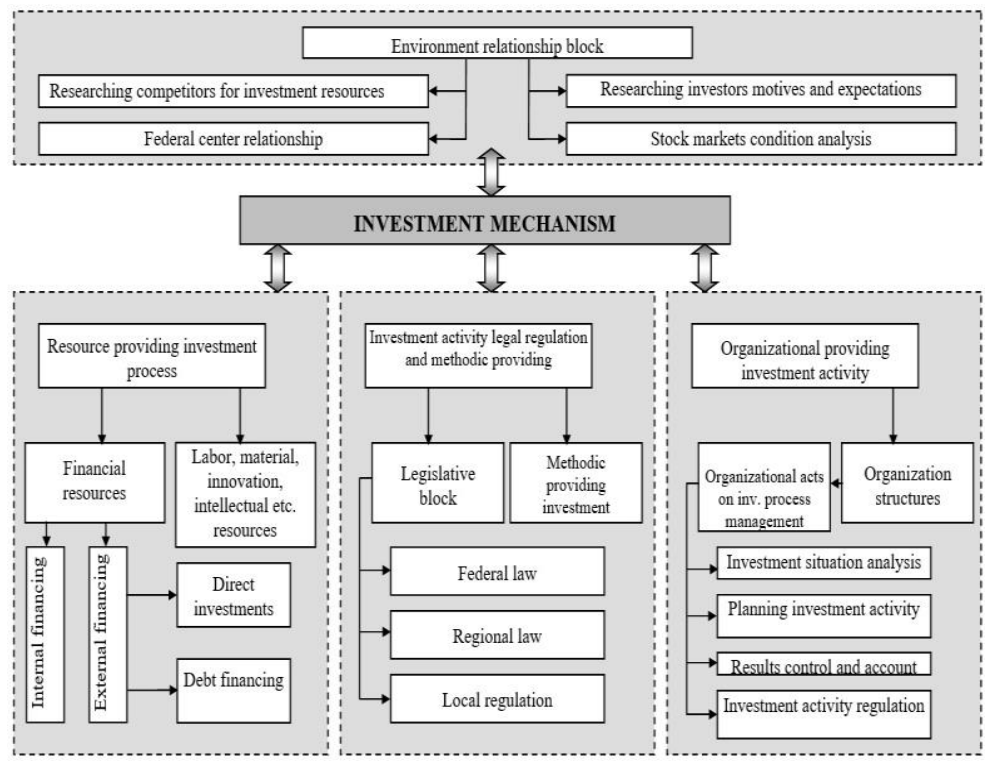

Fig. 1. Investment process management mechanism scheme.

Investment situation analysis in region and measures complex elaboration, destined on its improvements requires taking into account not only investment climate factors assessment, based on objective statistic information, but also subjective region investment attractiveness assessment for green projects realization by potential investors. It requires monitoring investors' reaction on investment climate change in region for chosen strategy realization mechanism correction. For this we suggest creating system of monitoring allowing, on complex figures system estimation, defining chosen strategy effectiveness in continuously changing environment conditions. The algorithm of management of investment process developed by authors within the concept of "green" economy is presented in figure 2 . 


\subsection{I stage. Defining regional investment policy aims according to green economy concept}

Key investment process management system elaboration moment in region is defining regional investment policy aims. Priorities in region development concept basis impact regional investment policy aims system in social-ecological-economic sphere.

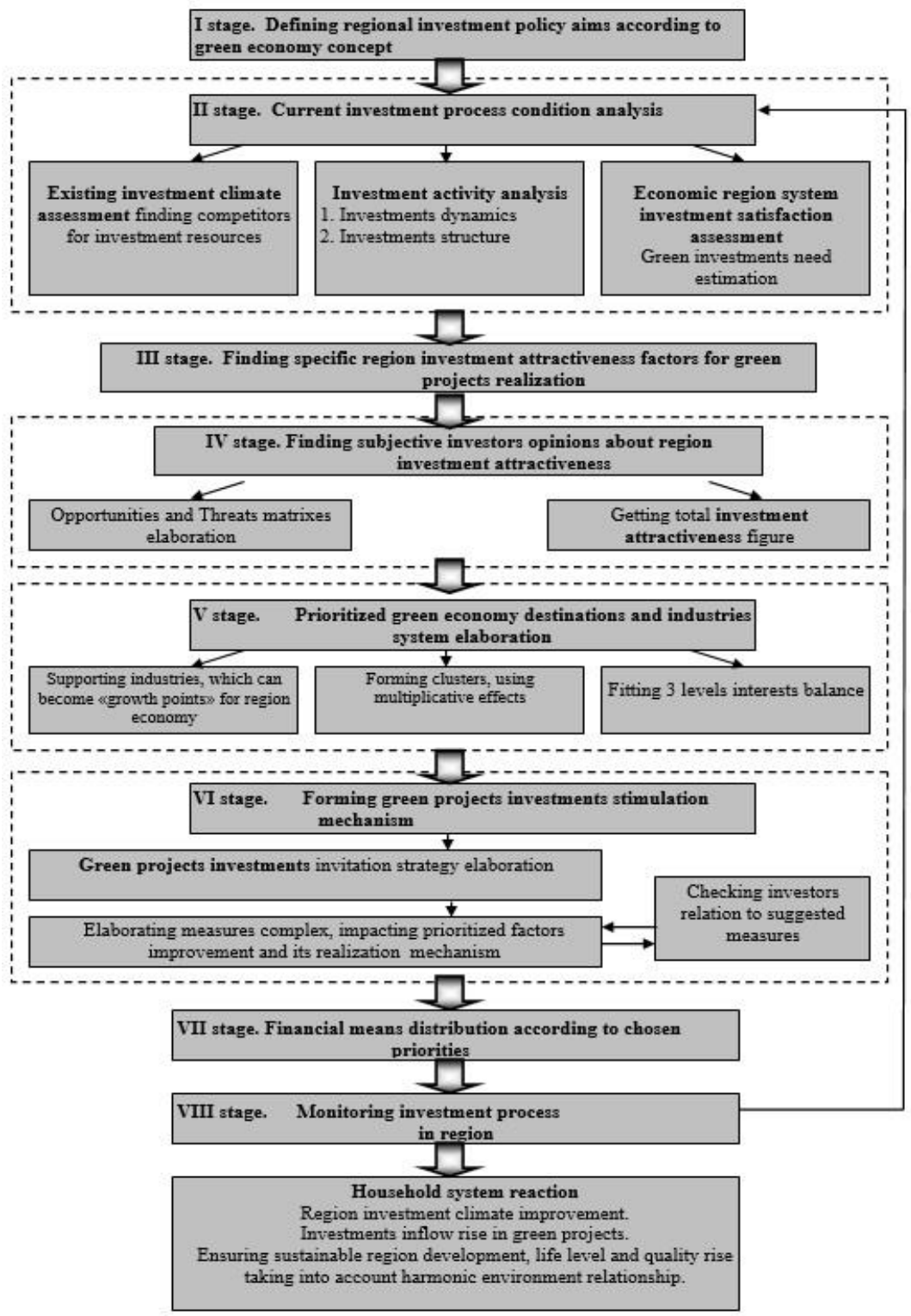

Fig. 2. Investment process management stages in region according to green economy concept.

\subsection{II stage. Current investment process condition analysis}


Effective management system elaboration follows economic system diagnostics, based on factor analysis. Thus, next stage is current investment process condition analysis in region. It includes the following actions consequence:

- Existing investment climate assessment with investment climate diagnostic algorithm for several factors groups' private and integral indexes calculation on statistic data base.

- Defining basic competitors for investment resources. Mechanisms of financing green investment projects have no sufficient differences from mechanisms of financing traditional projects, which inevitable leads to their competition for investment resources. Green projects have high social and ecological sufficiency, but because of technologies new and low markets knowledge green investment projects are more cost and risked for investors. Thus, regional power for capital transfer from mood to green investments needs additional stimuli.

- Investment activity analysis. Necessary is dynamical and structural investment activity analysis in region, and also assessing degree of investment activity level fitting to investment climate. Need in investments is defined on basis of regional investment policy aims, region internal and external environment analysis and current investment process condition.

\subsection{III stage. Specific region investment attractiveness factors analysis for green projects realization}

Because Russian Federation regions have specific features of development and functioning, it causes specialties in forming their investment attractiveness for green projects realization, and also fuzzy number and content of analytical figures, used in its estimation. It requires finding these specific factors in particular region for including into integral figure. It allows finding subject strengths and weaknesses, and on their base defining opportunities and threats for investing in this region [15].

\subsection{IV stage. Finding subjective investors' perceptions about region investment attractiveness}

Because, assessing investment climate, investor includes his subjective opinions into its characteristic, meaning attractive investment climate, maximally fit to his opinions and expectations. Thus investment attractiveness will be determined with not only region investment climate, but also subjective investors preferences and expectations.

Thus, work on forming favorable investment climate follows defining, which its characteristics seem most attractive, and which - most unattractive, and also their sufficiency for decision-making about investment. For this we suggest use expert assessment method, defining total region investment attractiveness figure and forming matrix complete, including Opportunities and Threats matrixes, allowing finding prioritized destinations of region green economy and investment attractiveness.

\subsection{V stage. Prioritized green economy destinations and industries system elaboration}

Financial resources limitation and also different social-ecological-economic investment effectiveness level require choosing green economy destinations and industries, in which investing gives maximal effect for providing sustainable development, for creating most favorable conditions. Basic principles of forming prioritized destinations are the following: benefits for investments in destinations and industries, which can become «growth points» 
for region green economy; forming clusters and developing industries-consumers, using multiplicative effects from investing; taking into account interests motivation for investors and invested socially-economic system.

\subsection{VI stage. Forming investments stimulation mechanism for green projects}

This stage includes the following acts sequences: green region investment policy concept elaboration; investment attraction strategy elaboration for green projects; measures complex elaboration, impacting prioritized factors improvement; checking investors' relation to suggested measures; this measures complex realization mechanism elaboration.

\subsection{VII stage. Financial means distribution according to chosen priorities}

Financial resources limitation requires their rational distribution, continuous current situation analysis. New approach essence to budget means distribution consists in budget process accents transfer from «budget resources (costs) management» to «results management». It means that budget must be formed, according to region policy aims and plan results in green economy sphere, not only in short-term, but also in middle- and longterm times.

For more reasonable budget resources distribution on activity destinations we suggest mathematical model usage, allowing predicting controlled figures development level depending on set priorities and money means amount. Optimal limited budget resources volume distribution problem in prioritized destinations should be considered from conflict management point of view [16].

\subsection{VIII stage. Monitoring investment process in region}

Each household system investment climate characterized with high dynamism. Strengthening competition for investment resources, fast technologies development and change, growing diversification, completing business-processes and other factors require modern analytic instruments usage, allowing with enough trust degree controlling chosen strategy realization process in continuously changing environment conditions.

One of such instruments is investment process monitoring system in household system, including information collection, complex assessment on defined figures system and decision-making about need in chosen strategy realization destinations correction.

\subsection{IX stage. Household system reaction}

Region investment climate improvement and stimulating measures elaboration for investors will lead to investments inflow rise in green projects, which will ensure sustainable region development, life level and quality rise taking into account harmonic environment relationship.

More full-blown methods and instruments complex, providing investment process management system realization according to green economy concept is considered in $\mathrm{O}$. Rostova \& S. Suloeva inquiry work [13].

\section{Discussion}

According to the study, the pace of projects development in the field of alternative energy throughout the world is quite high due to the following factors: institutional (more than half 
of the countries of the world have developed legal acts regulating certain aspects of regulation in this sphere) and investment (growth of investments in this direction). The work analyzes activity in renewable energy sources in some countries $[4,6,7,9]$, which allows finding basic barriers for investments raise in this sphere and elaborating regions investment attractiveness raise mechanism for such projects realization.

Energy based on renewable energy sources in Russia develops mainly in three areas: solar energy, wind power and small hydropower. These directions are recorded in the state program documents: "The main directions of the state policy in the field of increasing the energy efficiency of the electric power industry through the use of renewable energy sources for the period up to 2024". Target indicators are set for them. Other areas of alternative energy are represented by single projects and do not have target indicators.

However, the study showed that the focus is primarily on organizational, technical and scientific problems in the field of renewable energy sources, while economic and financial issues that ensure the effective implementation of such projects are not given sufficient attention. There are no elaborated mechanisms and instruments of state support for the development of alternative energy projects, both at the federal and regional levels. According to various estimates, the transition to the best available technologies will require additional investments for the period up to 2030 in the amount of 8 to 13 trillion. rubles [19].

The main measures to stimulate alternative energy projects can be used:

- defining the strategic goals of the "green" development of the electric power industry, creating a system of indicators measuring the level of this development;

- creating a system of control and statistical reporting on the implementation of target indicators for capacity commissioning and electricity generation using renewable energy sources;

- elimination of barriers when connecting renewable energy installations to public networks;

- $\quad$ standardization and quality control of equipment for renewable energy sources;

- $\quad$ government funding of research and pilot projects in the field of alternative energy;

- formation of the methodology and methodologies for managing the efficiency of green investments based on the project approach;

- development and implementation of financial instruments and mechanisms, taking into account their specifics and the long duration of "green" investment projects;

- development of tax incentives and other incentives for enterprises implementing green investment projects (preferential rates on loans, government subsidies, tax incentives, accelerated depreciation).

These measures should be included in the mechanism for implementing the "green" development strategy not only at the federal but also at the regional level, which will allow for the fastest possible introduction of "green" approaches and technologies for the production of electricity in all regions.

\section{Conclusion}

Thus, the findings obtained as a result of the work were formed and presented for further use for the activities of the project management of the company. The concept of managing the investment process in the region under the conditions of transition to a green economy has been added, based on its presentation as a targeted influence on the part of regional authorities on the system of investment activity conditions in order to maximize its compliance with investors' needs and stimulate their investment activity in the green areas In particular, in projects of alternative energy. 
Elaborated management algorithm allows finding specific regions investment attractiveness factors for alternative energy projects, forming measures complex for its raise and increase investments inflow to green projects. Increasing the share of generation based on renewable energy sources will help solve the problems of the deficient energy supply of technologically isolated territories of Russia and the preservation of environmental and recreational zones in Russia.

This paper was financially supported by the Ministry of Education and Science of the Russian Federation on the programm to improve the competitiveness of Peter the Great St.Petersburg Polytechnic University (SPbP) among the world's leading research and education centres in the 2016-2020.

\section{References}

1. V.B. Svalova, Monitoring. Science and technology 3, 82-97 (2015)

2. I.A. Yakovlev, L.S. Kabir, Financial Journal 3(37), 9-21 (2017)

3. S.M. Nikonorov, Russian Political Science 3, 12-15 (2017)

4. Y. Naumova, Problems of management theory and practice 10, 57-61 (2016)

5. S. Gzenger, V. Elistratov, R. Denisov, Wind power in Russia: prospects, opportunities and barriers, REENCON, 216-220 (2016)

6. J.G. Rueda-Bayona, A. Guzmán, J.C. Eras, Journal of Cleaner Production 220, 529543 (2019)

7. D. Xia, M. Zhang, Q. Yu, Y. Tu, Resources, Conservation and Recycling, 99-110 (2019)

8. A. Izotov, O. Rostova, A. Dubgorn, E3S Web of Conferences 33, 03008 (2018)

9. J.G. Dedecca, R.A. Hakvoort, P.M. Herder, Energy Research and Social Science 52, 5567 (2019)

10. A.S. Sokolitsyn, M.V. Ivanov, N.A. Sokolitsyna, V.P. Semenov, SCM 2016, 529-530 (2016)

11. W. Du, M. Li, Applied Economics 51, 2754-2763 (2019)

12. D. Zhang, Z. Rong, Q. Ji 144, 48-55 (2019)

13. S.B. Suloeva, O.V. Rostova, Management of the investment process in the region (the concept, methods, tools) (2009)

14. I. Aleksandrov, M. Fedorova, MATEC Web of Conferences 170, 01011 (2018)

15. A.V. Izotov, O.V. Rostova, Proceedings of the 29th International Business Information Management Association Conference, 1822-1832 (2017)

16. O. Rostova, S. Shirokova, A. Shmeleva, MATEC Web of Conferences 170, 01024 (2018).

17. T.V. Alesinskaya, D.V. Arutyunova, V.G. Orlova, I.V. Ilin, S.V. Shirokova, Conception BSC for investment support of port and industrial complexes, Academy of Strategic Management Journal (2017)

18. A.S. Sokolitsyn, M.V. Ivanov, N.A. Sokolitsyna, Proceedings of the 28th International Business Information Management Association Conference, 2122-2129 (2016)

19. L.V. Eder, I.V. Filimonova, I.V. Provornaya, Energy: economics, technology, ecology 2, 46-55 (2015) 